\title{
Phenolic compounds, organic acids and antioxidant activity of grape juices produced from new Brazilian varieties planted in the Northeast Region of Brazil
}

\author{
Marcos dos Santos Lima ${ }^{\mathrm{a}, 1}$, Igor de Souza Veras Silani ${ }^{\mathrm{a}, 1}$, Isabela Maia Toaldo ${ }^{\mathrm{b}, 2}$, Luiz Claudio Corrêa ${ }^{\mathrm{c}}$, \\ Aline Camarão Telles Biasoto ${ }^{\mathrm{c}, 3}$, Giuliano Elias Pereira ${ }^{\mathrm{d}, 4}$, Marilde T. Bordignon-Luiz ${ }^{\mathrm{b}, 2}$, \\ Jorge Luiz Ninow ${ }^{\mathrm{e}, *}$ \\ a Instituto Federal do Sertão Pernambucano, Campus Petrolina, Coordenação de Tecnologia de Alimentos, Jardim São Paulo - 56314-520, Petrolina, PE, Brazil \\ ${ }^{\mathrm{b}}$ Universidade Federal de Santa Catarina, Departamento de Ciência e Tecnologia de Alimentos, Rod. Admar Gonzaga 1346, Itacorubi - 88034-001, Florianópolis, SC, Brazil \\ ${ }^{\mathrm{C}}$ Empresa Brasileira de Pesquisa Agropecuária - Embrapa Semiárido, Rodovia BR 428, Km 152, CEP 56302-970 Petrolina, PE, Brazil \\ ${ }^{\mathrm{d}}$ Empresa Brasileira de Pesquisa Agropecuária - Embrapa Semiárido/Uva e Vinho, Rodovia BR 428, Km 152, CP 23, CEP 56302-970 Petrolina, PE, Brazil \\ ${ }^{\mathrm{e}}$ Universidade Federal de Santa Catarina, Departamento de Engenharia de Alimentos, Campus Universitário, Trindade - 88040-900, Florianópolis, SC, Brazil
}

\section{A R T I C L E I N F O}

\section{Article history:}

Received 13 January 2014

Received in revised form 21 March 2014

Accepted 22 March 2014

Available online 1 April 2014

\section{Keywords:}

Grape juice

Bioactive compounds

Tropical viticulture

\begin{abstract}
A B S T R A C T
The phenolic compounds, organic acids and the antioxidant activity were determined for grape juice samples from new Brazilian varieties grown in the Sub-middle São Francisco Valley in the Northeast Region of Brazil. The results showed that the Brazilian grape juices have high antioxidant activity, which was significantly correlated with the phenolic compounds catechin, epicatechin gallate, procyanidin B1, rutin, gallic acid, caffeic acid, p-coumaric acid, pelargonidin-3-glucoside, cyanidin-3-glucoside, cyaniding-3,5-diglucoside and delphinidin-3-glucoside. The produced juice samples showed higher concentrations of trans-resveratrol than those observed in juices made from different varieties of grapes from traditional growing regions. Organic acids concentrations were similar to those of juices produced from other classical varieties. It was demonstrated that it is possible to prepare juices from grapes of new varieties grown in the Northeast of Brazil containing a high content of bioactive compounds and typical characteristics of the tropical viticulture practised in the Sub-middle São Francisco Valley.
\end{abstract}

(c) 2014 Elsevier Ltd. All rights reserved.

\section{Introduction}

The global production of grape juices is estimated to be around 11-12 million hectoliters and the main producer and consumer countries are the United States of America, Brazil and Spain (OIV, 2013). In Brazil grape juice production has been increasing for some years, and Rio Grande do Sul State is the main producer of grapes and their derivatives, where the production increased from 126.9 million L in 2008 to 220 million L in 2012 (Mello, 2013).

\footnotetext{
* Corresponding author. Tel.: +55 483331 9448; fax: +55 4833319687 .

E-mail addresses: marcos.santos@ifsertao-pe.edu.br (Marcos dos Santos Lima), igorsilani@gmail.com (Igor de Souza Veras Silani), bela.toaldo@gmail.com (I.M. Toaldo), claudio.correa@embrapa.br (L.C. Corrêa), aline.biasoto@embrapa.br (A.C.T. Biasoto), giuliano.pereira@embrapa.br (G.E. Pereira), marilde.bordignon@ufsc.br (M.T. Bordignon-Luiz), jorge@enq.ufsc.br (J.L. Ninow).

1 Tel.: +558721014330.

2 Tel.: +554837215376.

3 Tel.: +55873866 3723 .

4 Tel.: +55 8738663711 .
}

Brazilian grape juices are produced from American hybrid grapes (Vitis labrusca) of the varieties Isabel, Bordô and Concord (Rizzon \& Miele, 2012). In contrast, in the United States grape juices are mainly produced from Concord cultivars and Muscadine (Vitis rotundifolia) varieties (Iyer, Sacks, \& Padilla-Zakour, 2010).

The Sub-middle region of the São Francisco Valley (SFV), located in the Northeast of Brazil at latitude 8 to $9^{\circ} \mathrm{S}$ and longitude $40 \mathrm{~W}$, with a tropical semi-arid climate, has received considerable interest from the wine production sector. This region is the second biggest producer of refined grapes and wines in Brazil, and represents more than $95 \%$ of the national grape exportation (Mello, 2013). Recently, there has been notable investment in the large-scale commercial production of grape juice in this region. An important difference between the tropical viticulture practised in the SFV and that of other traditional regions of the world is that in the SFV each vine can produce two harvests per year. Also, since this is a region with hot weather, high luminosity and abundant water for irrigation, wineries operate according to a particular scheme, evaluating the best period in which to harvest the grapes and to 
prune the vines. Also, the "step" system can be applied, where the harvesting is distributed within a certain period (e.g., one month, several months or the whole year) (Camargo, Tonietto, \& Hoffmann, 2011). Thus, it is possible to prepare grape juices throughout the year.

The vines planted in the Sub-middle SFV whose grapes are destined for the production of juices are of the cultivar Isabel Precoce (V. labrusca) and the hybrids BRS Cora and BRS Violeta. Also, although still in an experimental phase, the hybrid BRS Magna is planted, which is one of the new Brazilian varieties developed with the aim of improving the quality of grape juices (Camargo et al., 2011; Ribeiro, Lima, \& Alves, 2012; Ritschel et al., 2012). Isabel Precoce is originally from a spontaneous somatic mutation of the variety Isabel and it offers good productivity, anticipated maturation and the same characteristics as the original cultivar (Camargo, 2004). The hybrid varieties BRS Cora and BRS Violeta are used to improve the colour of juices when required, and the use of a proportion of $15-20 \%$ in the juice formulation is recommended (Camargo, Maia, \& Nachtigal, 2005). In relation to climate, the hybrid variety BRS Magna is widely adaptable and it is used for the production of juice with good colour and also with the typical aroma of $V$. labrusca (Ritschel et al., 2012). The first large-scale commercial juice production plants in the São Francisco Valley used mixtures of $80 \%$ Isabel Precoce with $20 \%$ BRS Cora or $20 \%$ BRS Violeta, to obtain products with good colour intensity.

Grape juices are rich in phenolic compounds and different studies have demonstrated that these substances possess biological activity related to health benefits for the consumers (Krikorian et al., 2012; Vauzour, Rodriguez-Mateos, Corona, Oruna-Concha, \& Spencer, 2010). The phenolic compounds in grape juices, mainly the flavonoids flavanols, flavonols and anthocyanins, are associated with improved health, along with other compounds which are not flavonoids, such as phenolic acids and the stilbene resveratrol (Ali, Maltese, Choi, \& Verpote, 2010; Krikorian et al., 2012; Sautter et al., 2005; Xia, Deng, Guo, \& Li, 2010). The flavonols are represented mainly by kaempferol, quercetin and myricetin and simple orthomethylated derivatives such as isorhamnetin, which have received considerable interest due to their antioxidant properties (Mudnic et al., 2010). Among the flavanols, (+)-catechin, (-)-epicatechin and procyanidins have gained attention due to their antioxidant, antimicrobial and bactericidal activity (Xia et al., 2010). The principal anthocyanins found in juices are malvidin, cyanidin, delphinidin, petunidin, peonidin and pelargonidin. The consumption of these anthocyanins is associated to biological activities, such as antioxidant capacity and prevention of cardiovascular diseases (Oh et al., 2008; Xia et al., 2010). Phenolic acids, such as gallic, caffeic and chlorogenic, have been studied for their antioxidant capacity and for acting as venous dilators (Mudnic et al., 2010). Also, stilbenes, particularly trans-resveratrol (trans-3,5,4'-trihydroxystilbene), have been associated with many health benefits including bactericidal, fungicidal, cardio-protection and anticancer activity as well as increased longevity in humans (Ali et al., 2010).

Several types of biological activity are related to phenolic compounds and antioxidant capacity, which is the one most commonly investigated, is mainly associated with flavonoid compounds, although this property has also been reported for non-flavonoids. The results obtained for the quantification of antioxidant activity can vary according to the method used (Muselík, García-Alonso, Martín-López, Žemlička, \& Rivas-Gonzalo, 2007). For grape juices several techniques have been tested (Burin et al., 2010; Dani et al., 2007; Dávalos, Bartolome, \& Gómez-Cordove's, 2005). The International Organization of Vine and Wine (OIV) recommends the use of a sensitive colorimetric free radical scavenger method using 2,2-diphenyl-1-picrylhydrazyl reagent (DPPH) (Organisation Internationale de la Vigne et du Vin, 2011).
Other interesting and important compounds in grape juices are the organic acids, due to their influence on the organoleptic properties such as flavor, taste, colour and aroma. They also affect the juice stability and are used as indicators of microbiological alterations in the beverage. In particular, the presence of acetic acid is an indicator of unwanted microbiological changes (Ali et al., 2010). The organic acids in grape juices are similar to those found in the must of fresh grapes, with tartaric and malic acids being predominant and succinic and citric acids being present in smaller amounts (Soyer, Koca, \& Karadeniz, 2003). These compounds are associated with the typical characteristics of grape juices (Camargo, 2004).

Several factors including the grape variety, processing technique, viticultural practise and geographical region exert a significant influence on the phenolic composition and antioxidant activity of juices (Dani et al., 2007; Fuleki \& Ricardo-da-Silva, 2003; Leblanc, Johnson, \& Wilson, 2008; Natividade, Corrêa, Souza, Pereira, \& Lima, 2013; Talcott \& Lee, 2002). In order to evaluate the bioactive phenolic potential of grape juices, the objective of this investigation was to determine in vitro the phenolic compounds and organic acids content, along with the antioxidant activity, of juices produced from $V$. labrusca grapes of the varieties and hybrids planted at the Sub-middle region of the São Francisco Valley in the Northeast region of Brazil.

\section{Materials and methods}

\subsection{Chemicals}

Ethyl alcohol, potassium persulfate and Folin-Ciocalteu reagent were obtained from Merck (Darmstadt, Germany). Trolox (6-hydroxy-2,5,7,8-tetramethylchroman-2-carboxylic acid), 2,2diphenyl-1-picrylhydrazyl (DPPH) and 2,2-azino-bis(3-ethylbenzthiazoline-6-sulfonic acid) (ABTS) were purchased from Sigma-Aldrich (St. Louis, MO, USA). Methanol, acetonitrile and 85\% phosphoric acid were obtained from Vetec Chemistry Ltda (Rio de Janeiro, Brazil), J.T. Baker (Phillipsburg, NJ, USA) and Fluka (Switzerland), respectively. Tartaric, malic, citric, succinic, lactic, acetic and ascorbic acids were purchased from Vetec chemistry Ltda (Rio de Janeiro, Brazil). Ultra-pure water was obtained by purification using a Purelab Option Q Elga System (USA). Malvidin 3,5-diglucoside, cyanidin 3,5-diglucoside, malvidin 3-glucoside, cyanidin 3-glucoside, peonidin 3-glucoside, delphinidin 3-glucoside and pelargonidin 3-glucoside, kaempferol 3-glucoside, myricetin, quercetin, rutin (quercetin 3-rutinoside), isorhamnetin 3-glucoside, (+)-catechin, (-)-epicatechin, (-)-epicatechin gallate, (-)-epigalocatechin, procyanidins A2, B1 and B2, and trans-resveratrol were purchased from Extrasynthese (Genay, França). Gallic acid, cinnamic acid and caffeic acid were purchased from Chem Service (West Chester, USA). $p$-Coumaric and chlorogenic acid were obtained from Sigma-Aldrich (St. Louis, MO, USA).

\subsection{Grape samples}

The grapes of the Isabel Precoce and BRS Violeta varieties were collected from a specific area destined for the production of commercial juice at the Fazenda Fujiyama which forms part of the Cooperativa Agrícola Nova Aliança (COANA), located at Projeto Senador Nilo Coelho - Núcleo 4, lote 56, Zona Rural, Petrolina, Pernambuco State, Brazil, situated at $09^{\circ} 21^{\prime} \mathrm{S}$ latitude and $40^{\circ} 40^{\prime} \mathrm{W}$ longitude, at an altitude of approximately $360 \mathrm{~m}$. The grapes of BRS Cora and BRS Magna varieties were harvested at the experimental vineyard Fazenda Timbaúba Agrícola located at Rodovia BR 122, km 174, PISNC Núcleo 11, Zona Rural, Petrolina Pernambuco State, Brazil, situated at latitude $09^{\circ} 11^{\prime} \mathrm{S}$ and longitude $40^{\circ}$ 
$29^{\prime} \mathrm{W}$. The grape juices were produced at an industrial plant belonging to COANA, located at Projeto Senador Nilo Coelho Núcleo 2, lote 551, Zona Rural, Petrolina, Pernambuco State, Brazil.

The plants were growing in vineyards with an average age of 2 years, grafted on Paulsen 1103 rootsock, planted in a field with 3.5 and $3.0 \mathrm{~m}$ of spacing between lines and plants, respectively, and following a trellis system. The irrigation system was of the type micro-aspersion and the vineyards were pruned (production pruning) on June 25th, 2012 and the grapes were harvested from October 15th to 19th, 2012, when they reached the required standard maturation: soluble solids (Brix degree) between 18 and 21, titratable acidity (TA) from 0.7 to $0.9 \mathrm{~g} 100 \mathrm{~mL}^{-1}$ of must, expressed as tartaric acid, and ${ }^{\circ} \mathrm{Brix} / \mathrm{TA}$ ratio between 20 and 26.

The climatic data (average/month) for the region in the months of June and October 2012, that is, from pruning to harvest time, were: temperature $25.6^{\circ} \mathrm{C}$, rainfall $1.8 \mathrm{~mm}$, relative humidity $54 \%$, evaporation $8.2 \mathrm{~mm}$, illuminance $486.8 \mathrm{~lx} /$ day and insolation $8.5 \mathrm{~h}$, measured at the weather station in Bebedouro (Petrolina, Pernambuco State, Brazil, $09^{\circ} 09^{\prime} \mathrm{S} 40^{\circ} 22^{\prime} \mathrm{W}$ ).

\subsection{Preparation of Grape juices}

All juices were obtained by hot extraction without bagasse pressing, in an in-line system manufactured by JAPA ${ }^{\circledR}$ (Garibaldi, Rio Grande do Sul State, Brazil). The grapes were destemmed and crushed in an automatic destemmer-crusher machine DZ-35 model, with the addition of an enzymatic liquid mixture based on pectinase called Endozym ${ }^{\circledR}$ Pectofruit PR, produced by Spindal - Pascal Biotech (Gretz-Armainvilliers, France) at a dose of $3.0 \mathrm{~mL}$ per $100 \mathrm{~kg}$ of fresh grapes. The grapes were then pumped into a maceration tank with controlled temperature and the mixture was heated to $60^{\circ} \mathrm{C}$ and held at this temperature for $1 \mathrm{~h}$ with constant pumping of the liquid. After maceration the juice was separated by draining, aided by pump suction. The procedure did not require pressing of the bagasse. The juice was homogenised and then subjected to pasteurisation at $85^{\circ} \mathrm{C}$ for $60 \mathrm{~s}$ in a plate pasteurizer. The samples were then packaged, through hot filling of non-coloured glass bottles of $1 \mathrm{~L}$ capacity manufactured by SaintGobain $^{\circledR}$ (São Paulo-SP, Brazil), using a gravimetric automatic filling machine (EVR12 model). The filled bottles were capped, closed and tumbled. The closed bottles were cooled in a cooling tunnel by water spraying until reaching an average temperature of $45^{\circ} \mathrm{C}$.

The following juices were produced: Isabel Precoce $100 \%$ - Juice IP, BRS Cora 100\% - Juice BC, BRS Violeta 100\% - Juice BV, BRS Magna 100\% - Juice BM, Commercial blend of Isabel Precoce $80 \%$ and BRS Violeta 20\% - Juice IPBV and Commercial blend of Isabel Precoce $80 \%$ and BRS Cora $20 \%$ - Juice IPBC.

\subsection{Quality analysis - classic parameters and colour}

The analysis of the juice quality was carried out by determining the $\mathrm{pH}$ (potentiometer pH Analyser - Tecnal (Brazil)); soluble solids (SS), ${ }^{\circ}$ Brix (digital refractometer HI 96801 Hanna ${ }^{\circledR}$, USA) and tritatable acidity (TA), following the methodologies described in Organisation Internationale de la Vigne et du Vin (2011). The colour intensity $(\mathrm{CI})$ was determined by obtaining the indices at 420, 520 and $620 \mathrm{~nm}$ with a UV-Vis UV 2000A spectrophotometer, Instrutherm $^{\circledR}$ (Brazil), using glass cuvettes with a path length of $0.5 \mathrm{~cm}$.

\subsection{Bioactive content - total phenolics and total monomeric anthocyanins}

The total phenolic compounds contents of the grape juices were determined spectrophotometrically using the Folin-Ciocalteu method (Singleton \& Rossi, 1965). The absorbance value obtained in tests at $765 \mathrm{~nm}$ was compared with a calibration curve obtained for gallic acid and the results expressed as $\mathrm{mg} \mathrm{L}^{-1}$ gallic acid equivalent (GAE). The analysis to determine the total monomeric anthocyanins content was carried out using the pH-differential method described by Giusti and Wrolstad (2001). The juice samples were diluted with buffer solutions of $\mathrm{KCl}(0.025 \mathrm{M}, \mathrm{pH}=1.0)$ and of $\mathrm{CH}_{3-}$ COONa $(0.4 \mathrm{M}, \mathrm{pH}=4.5)$, and readings were taken at $520 \mathrm{~nm}$ and $700 \mathrm{~nm}$ on spectrophotometer. The concentrations of pigments in the juices were expressed as cyanidin-3-glucoside equivalents in $\mathrm{mg} \mathrm{L}^{-1}$.

\subsection{HPLC determination of organic acids}

The quantification of tartaric, malic, citric, lactic, succinic, acetic and ascorbic acids was carried out by high-performance liquid chromatography (HPLC) using a WATERS (model Aliance e2695) chromatograph coupled with diode-array detection (DAD). The juice samples were filtered through a $0.45 \mu \mathrm{m}$ membrane and injected in triplicate. For the acid determination the DAD wavelength was maintained at $250 \mathrm{~nm}$ for ascorbic acid and $210 \mathrm{~nm}$ for tartaric, malic, citric, lactic, succinic and acetic acids, with a run time of $15 \mathrm{~min}$, flow rate of $0.6 \mathrm{~mL} \mathrm{~min}^{-1}$ at $26{ }^{\circ} \mathrm{C}$ and volume injection of $10 \mu \mathrm{L}$. The column used was a Gemini-NX C18 $(150 \times 4.60 \mathrm{~mm}$, with $3 \mu \mathrm{m}$ internal particles $)$ and the pre-column was a Gemini-NX C18 $(4.0 \times 3.0 \mathrm{~mm})$, both manufactured by Phenomenex ${ }^{\circledR}$. The mobile phase comprised a $0.025 \mathrm{M}$ solution of $\mathrm{KH}_{2-}$ $\mathrm{PO}_{4}$ acidified with $\mathrm{H}_{3} \mathrm{PO}_{4}$ until pH 2.6. In relation to the linearity of the method, the $R^{2}$ values obtained ranged from 0.9984 to 0.9998 . The lower and upper values for the limits of detection (LOD) were 0.03 and $3.59 \mathrm{mg} \mathrm{L}^{-1}$, respectively, for ascorbic and citric acids.

\subsection{HPLC analysis of phenolic compounds}

The phenolic compounds were determined by HPLC on a WATERS chromatograph (model Aliance e2695), equipped with a quaternary solvent pump and automatic injector, coupled with DAD and fluorescence detection (FD), according to the methodology described by Natividade et al. (2013). The data collection and analysis were carried out using the software Empower ${ }^{\mathrm{TM}} 2$ (Milford, EUA). In the DAD, the detection of compounds was performed at $220 \mathrm{~nm}$ for gallic acid (LOD $=0.07 \mathrm{mg} \mathrm{L}^{-1}, R^{2}=0.998$ ), (-)-epicatechin gallate (LOD $\left.=0.07 \mathrm{mg} \mathrm{L}^{-1}, R^{2}=0.991\right)$, (-)-epigalocatechin (LOD $\left.=0.19 \mathrm{mg} \mathrm{L}^{-1}, \quad R^{2}=0.999\right)$ and procyanidin B1 $\left(\mathrm{LOD}=0.03 \mathrm{mg} \mathrm{L}^{-1}, R^{2}=0.999\right) ; 320 \mathrm{~nm}$ for $t$-resveratrol $(\mathrm{LOD}=$ $0.01 \mathrm{mg} \mathrm{L}^{-1}, \quad R^{2}=0.999$ ), caffeic acid (LOD $=0.08 \mathrm{mg} \mathrm{L}^{-1}$, $R^{2}=0.998$ ), cinnamic acid (LOD $=0.11 \mathrm{mg} \mathrm{L}^{-1}, R^{2}=0.999$ ), $p$-coumaric acid (LOD $=0.05 \mathrm{mg} \mathrm{L}^{-1}, R^{2}=0.999$ ) and chlorogenic acid ( $\mathrm{LOD}=0.02 \mathrm{mg} \mathrm{L}^{-1}, R^{2}=0.998$ ); $360 \mathrm{~nm}$ for the flavonols kaempferol (LOD $\left.=0.06 \mathrm{mg} \mathrm{L}^{-1}, R^{2}=0.998\right)$, myricetin (LOD $=0.01 \mathrm{mg} \mathrm{L}^{-1}$, $\left.R^{2}=0.999\right)$, quercetin ( $\left.\mathrm{LOD}=0.002 \mathrm{mg} \mathrm{L}^{-1}, R^{2}=0.999\right)$, rutin ( $\mathrm{LOD}=0.04 \mathrm{mg} \mathrm{L}^{-1}, R^{2}=0.999$ ) and isorhamnetin (LOD $=0.01$ $\left.\mathrm{mg} \mathrm{L}^{-1}, R^{2}=0.998\right)$; and $520 \mathrm{~nm}$ for the anthocyanins malvidin 3,5-diglucoside (LOD $=0.06 \mathrm{mg} \mathrm{L}^{-1}, R^{2}=0.999$ ), cyanidin 3,5-diglucoside ( $\mathrm{LOD}=0.04 \mathrm{mg} \mathrm{L}^{-1}, R^{2}=0.998$ ), malvidin 3-glucoside ( $\mathrm{LOD}=0.03 \mathrm{mg} \mathrm{L}^{-1}, R^{2}=0.997$ ), cyanidin 3-glucoside ( $\mathrm{LOD}=0.11$ $\mathrm{mg} \mathrm{L}^{-1}, \quad R^{2}=0.998$ ), peonidin 3-glucoside ( $\mathrm{LOD}=0.01 \mathrm{mg} \mathrm{L}^{-1}$, $R^{2}=0.997$ ), delphinidin 3-glucoside ( $\mathrm{LOD}=0.09 \mathrm{mg} \mathrm{L}^{-1}, \quad R^{2}=$ 0.999 ) and pelargonidin 3-glucoside (LOD $=0.04 \mathrm{mg} \mathrm{L}^{-1}, R^{2}=$ $0.983)$. In the FD, the photon excitation was carried out at $280 \mathrm{~nm}$ and the emission at $320 \mathrm{~nm}$ for $(+)$-catechins (LOD = $\left.0.01 \mathrm{mg} \mathrm{L}^{-1}, \quad R^{2}=0.988\right)$, procyanidin B2 (LOD $=0.001 \mathrm{mg} \mathrm{L}^{-1}$, $R^{2}=0.983$ ), procyanidin A2 (LOD $=0.003 \mathrm{mg} \mathrm{L}^{-1}, R^{2}=0.990$ ) and (-)-epicatechin ( $\mathrm{LOD}=0.01 \mathrm{mg} \mathrm{L}^{-1}, R^{2}=0.983$ ).

The column used was a Gemini-NX C18, $150 \times 4.60 \mathrm{~mm}$, with $3 \mu \mathrm{m}$ internal particles, and the pre-column was a Gemini-NX $\mathrm{C} 18,4.0 \times 3.0 \mathrm{~mm}$, both manufactured by Phenomenex ${ }^{\circledR}$. The oven 
temperature was maintained at $40{ }^{\circ} \mathrm{C}$, the injection volume was $10 \mu \mathrm{L}$ (juice previously filtered through a $0.45 \mu \mathrm{m}$ membrane; Allcrom-Phenomenex, USA) and the flow rate was $0.5 \mathrm{~mL} \mathrm{~min}^{-1}$. The mobile phase consisted of $0.85 \%$ phosphoric acid solution (solvent A) and acetonitrile (solvent $B$ ). The gradient elution was: 0 min: 100\% $\mathrm{A} ; 10 \mathrm{~min}: 93 \% \mathrm{~A}$ and $7 \% \mathrm{~B} ; 20 \mathrm{~min}: 90 \% \mathrm{~A}$ and $10 \% \mathrm{~B}$; 30 min: $88 \% \mathrm{~A}$ and $12 \% \mathrm{~B} ; 40 \mathrm{~min}$ : $77 \% \mathrm{~A}$ and $33 \% \mathrm{~B} ; 45 \mathrm{~min}: 65 \%$ $\mathrm{A}$ and $35 \% \mathrm{~B}$ and $55 \mathrm{~min}: 100 \% \mathrm{~B}$.

\subsection{Antioxidant activity of grape juices}

The in vitro antioxidant activity of the grape juices was determined using the DPPH radical scavenging method (Kim, Guo, \& Packer, 2002) and the ABTS radical scavenging method (Re et al., 1999). For both methods, the analytical standard Trolox was used to construct the calibration curves and the results were expressed as equivalents of Trolox per litre of grape juice (mM TEAC $\mathrm{L}^{-1}$ ). Absorbance measurements were performed on a UV-Vis L-2010 Hitachi ${ }^{\circledR}$ spectrometer (Tokyo, Japan).

In the DPPH method, the antioxidant activity of the grape juices was assessed through the rate of decay in the absorbance at $517 \mathrm{~nm}$. The DPPH radical (2,2-diphenyl-1-picrylhydrazyl) solution was prepared in ethanol and diluted to an absorbance of $0.900 \pm 0.050$. For each sample, the absorbance of the DPPH solution was determined at time $t=0 \mathrm{~min}$ and $30 \mathrm{~min}$ after the addition of grape juice $(t=30 \mathrm{~min})$.The procedure consisted of mixing $0.1 \mathrm{~mL}$ of each grape juice sample with $2.9 \mathrm{~mL}$ of $1.0 \mathrm{mM} \mathrm{DPPH}$ ethanolic solution. The mixture was kept in the dark for $30 \mathrm{~min}$, and the absorbance was read at $517 \mathrm{~nm}$.

The ABTS radical scavenging activity of the grape juices was determined through the rate of decay in the absorbance at $754 \mathrm{~nm}$. In this procedure, the ABTS solution (2,2-azino-bis(3-ethylbenzthiazoline-6-sulphonic acid)) was diluted with ethanol to an absorbance of $0.700 \pm 0.030$. For each sample, the absorbance of the ABTS solution $(940 \mu \mathrm{L})$ was determined at time $t=0 \mathrm{~min}$ and at time $t=6 \mathrm{~min}$ after the addition of $60 \mu \mathrm{L}$ of grape juice.

\subsection{Statistical analysis}

Data were collected for six grape juices produced in industrial large-scale and each juice was obtained from a processing tank containing $3000 \mathrm{~kg}$ of fresh grapes (with a total of 18,000 kg being used). The juices were: Isabel Precoce (IP), BRS Cora (BC), BRS Violeta (BV), BRS Magna (BM), and two commercial blends used by factories in the region, that is, Isabel Precoce $80 \%$ with BRS Violeta $20 \%$ (IPBV) and Isabel Precoce $80 \%$ with BRS Cora $20 \%$ (IPBC). The results obtained for the variables studied were subjected to analysis of variance (ANOVA) and followed by comparisons performed using the Tukey test with a probability of error of $5 \%$. The correlation analysis was also conducted (with $5 \%$ and $1 \%$ probability) to investigate the relation between the phenolic compounds content and antioxidant activity, with the aid of the SPSS version 17.0 statistical package for Windows (SPSS, Chicago, USA).

\section{Results and discussion}

\subsection{Quality analysis - classic parameters and colour intensity of grape juices}

The results for the quality parameters of the juices are presented in Table 1 . The values for the soluble solids (SS), titratable acidity (TA) and SS/TA ratio are similar to those recommended by the Brazilian legislation for grape juice, which establishes a minimum of $14{ }^{\circ}$ Brix for SS, minimum of $0.41 \mathrm{~g} 100 \mathrm{~mL}^{-1} \mathrm{TA}$ in the must, and an SS/TA ratio of between 14 and 45 (Brazil, 2000).
The mean values for the SS content $(20.3 \pm 0.5)$ in the juices prepared were higher than that obtained by Rizzon and Miele (2012) for commercial Brazilian juices (16.2 \pm 1.1 ). In regions with a tropical climate, such as the Sub-middle São Francisco Valley (SFV), where high temperatures and insolation dominate, the metabolism favours the synthesis and accumulation of sugar in the berries (Ribeiro et al., 2012). The colour intensity (CI) parameter demonstrated different characteristics among the varieties. The juices BV, BM and BC showed the highest colour intensity, with values of $11.15,9.05$ and 7.74, respectively, while IPBC and IPBV presented $\mathrm{CI}$ values of 5.29 and 7.07 , respectively. The $\mathrm{CI}$ value for these juices was significantly higher than that for IP (2.78). These results demonstrate that the use of the BRS Cora and BRS Violeta hybrid cultivars in blends could improve the colour of the juices, which is an important attribute in relation to grape juice quality.

\subsection{Organic acids}

The results for the organic acids content of the grape juices are shown in Table 1 where it can be observed that the values varied from 8.64 to $12.04 \mathrm{~g} \mathrm{~L}^{-1}$. The main organic acids present in the grape juices were tartaric acid (4.60-6.32 $\mathrm{g} \mathrm{L}^{-1}$ ) and malic acid (2.12-4.15 $\left.\mathrm{g} \mathrm{L}^{-1}\right)$. The results for the other organic acids were: citric acid $250-730 \mathrm{mg} \mathrm{L}^{-1}$, ascorbic acid $4.8-15.5 \mathrm{mg} \mathrm{L}^{-1}$ and lactic acid 190-643 $\mathrm{mg} \mathrm{L}^{-1}$. The juice BC did not contain detectable levels of succinic acid and the values for the rest of the juices varied between 153 and $203 \mathrm{mg} \mathrm{L}^{-1}$. Acetic acid was present in the samples in concentrations varying from 347 to $447 \mathrm{mg} \mathrm{L}^{-1}$.

The two main organic acids found in grape juices (tartaric and malic) represent more than $80 \%$ of the overall total acids. The concentrations of these two acids may vary depending on factors directly related with the grape, such as maturation stage, variety of grape and weather, as well as processes such as the detartration process, which involves a reduction in the concentration of tartaric acid (Liu, Wu, Fan, Li, \& Li, 2006; Ribeiro et al., 2012; Soyer et al., 2003). In a study by Liu et al. (2006) the organic acids concentrations in the must from 98 grape varieties, hybrids and Vitis vinifera, varied from 1.54 to $9.09 \mathrm{~g} \mathrm{~L}^{-1}$ for tartaric acid and 0.36 to $7.06 \mathrm{~g} \mathrm{~L}^{-1}$ for malic acid. Soyer et al. (2003) obtained variations in the concentrations of organic acids in the grapes of 12 varieties grown in Turkey, from 4.07 to $4.92 \mathrm{~g} \mathrm{~L}^{-1}$ for tartaric acid and from 1.36 to $3.47 \mathrm{~g} \mathrm{~L}^{-1}$ for malic acid.

Acetic acid is the main undesirable organic acid in juices, because its presence in high concentrations acts as an indicator of undesirable fermentation of the grapes must, which can be due to a lack of hygienic care of the raw material (Ali et al., 2010). Brazilian legislation establishes a maximum limit of $500 \mathrm{mg} \mathrm{L}^{-1}$ for acetic acid in grape juices (Brazil, 2000). Citric, succinic and ascorbic acids are present in the grape juices in small quantities. Soyer et al. (2003) obtained values of between 31 and $181 \mathrm{mg} \mathrm{L}^{-1}$ for citric acid in juices from different varieties. For ascorbic acid, Dani et al. (2007) obtained values of 4.4-57.2 $\mathrm{mg} \mathrm{L}^{-1}$ in juices produced from $V$. labrusca Bordô and Niágara varieties.

The values obtained for organic acids in this study are similar to those reported in the literature for several grape juices (Rizzon \& Miele, 2012; Soyer et al., 2003). In the case of acetic acid, the concentrations obtained comply with the limits established in Brazilian legislation for grape juices (Brazil, 2000).

The juice $\mathrm{BC}$ presented the highest concentration of tartaric and malic acids, with values of 6.32 and $4.15 \mathrm{~g} \mathrm{~L}^{-1}$, respectively, even though it was prepared with grapes harvested in the same maturation stage as the other varieties. Ribeiro et al. (2012) observed that grapes of this particular variety can have high soluble solids contents ( ${ }^{\circ}$ Brix), maintaining a high total tritratable acidity. Thus, they are recommended for use in juices since they can improve the 
Table 1

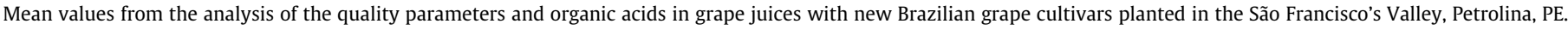

\begin{tabular}{|c|c|c|c|c|c|c|}
\hline \multirow[t]{2}{*}{ Classical parameters } & \multicolumn{6}{|l|}{ Juice } \\
\hline & IP & $\mathrm{BC}$ & BV & BM & IPBV & IPBC \\
\hline $\mathrm{pH}$ & $3.44 \pm 0.02^{\mathrm{b}}$ & $3.24 \pm 0.01^{\mathrm{c}}$ & $3.46 \pm 0.02^{\mathrm{b}}$ & $3.62 \pm 0.01^{\mathrm{a}}$ & $3.45 \pm 0.01^{\mathrm{b}}$ & $3.26 \pm 0.01^{\mathrm{c}}$ \\
\hline Soluble solids (SS) & $20.0 \pm 0.3^{c}$ & $21.0 \pm 0.1^{\mathrm{a}}$ & $20.2 \pm 0.1^{\mathrm{b}}$ & $20.3 \pm 0.1^{\mathrm{bc}}$ & $20.6 \pm 0.1^{\mathrm{b}}$ & $19.4 \pm 0.1^{\mathrm{d}}$ \\
\hline Tritratable acidity (AT) & $0.77 \pm 0.02^{\mathrm{d}}$ & $1.06 \pm 0.02^{\mathrm{a}}$ & $0.85 \pm 0.04^{\mathrm{c}}$ & $0.68 \pm 0.01^{\mathrm{e}}$ & $0.80 \pm 0.01^{\mathrm{cd}}$ & $0.94 \pm 0.01^{\mathrm{b}}$ \\
\hline Relation (SS/AT) & $26.2 \pm 0.9^{b}$ & $19.8 \pm 0.4^{\mathrm{d}}$ & $23.8 \pm 1.2^{c}$ & $29.9 \pm 0.3^{\mathrm{a}}$ & $25.8 \pm 0.2^{\mathrm{b}}$ & $20.7 \pm 0.2^{\mathrm{d}}$ \\
\hline Color intensity & $2.78 \pm 0.02^{f}$ & $7.74 \pm 0.01^{\mathrm{c}}$ & $11.15 \pm 0.01^{\mathrm{a}}$ & $9.05 \pm 0.01^{\mathrm{b}}$ & $5.29 \pm 0.01^{\mathrm{e}}$ & $7.07 \pm 0.01^{d}$ \\
\hline \multicolumn{7}{|l|}{ Organic acids } \\
\hline Tartaric $\left(\mathrm{g} \mathrm{L}^{-1}\right)$ & $5.26 \pm 0.02^{c}$ & $6.32 \pm 0.01^{\mathrm{a}}$ & $4.88 \pm 0.10^{\mathrm{e}}$ & $5.02 \pm 0.06^{\mathrm{d}}$ & $4.60 \pm 0.01^{\mathrm{f}}$ & $5.42 \pm 0.01^{\mathrm{b}}$ \\
\hline Malic $\left(\mathrm{g} \mathrm{L}^{-1}\right)$ & $2.12 \pm 0.03^{d}$ & $4.15 \pm 0.16^{\mathrm{a}}$ & $3.29 \pm 0.06^{\mathrm{b}}$ & $3.06 \pm 0.05^{\mathrm{b}}$ & $2.63 \pm 0.12^{c}$ & $2.54 \pm 0.05^{c}$ \\
\hline Citric $\left(\mathrm{mg} \mathrm{L}^{-1}\right)$ & $457 \pm 40^{\mathrm{b}}$ & $730 \pm 130^{\mathrm{a}}$ & $250 \pm 96^{c}$ & $287 \pm 12^{\mathrm{bc}}$ & $343 \pm 15^{\mathrm{bc}}$ & $270 \pm 17^{\mathrm{bc}}$ \\
\hline Ascorbic $\left(\mathrm{mg} \mathrm{L}^{-1}\right)$ & $4.8 \pm 1.2^{\mathrm{d}}$ & $10.5 \pm 3.6^{\mathrm{abc}}$ & $15.5 \pm 0.6^{\mathrm{a}}$ & $12.4 \pm 0.3^{\mathrm{ab}}$ & $9.1 \pm 2.0^{\mathrm{bcd}}$ & $6.7 \pm 1.2^{\mathrm{cd}}$ \\
\hline Lactic $\left(\mathrm{mg} \mathrm{L}^{-1}\right)$ & $190 \pm 10^{d}$ & $467 \pm 83^{b}$ & $390 \pm 26^{c}$ & $417 \pm 20^{\mathrm{b}}$ & $643 \pm 116^{a}$ & $227 \pm 32^{\mathrm{cd}}$ \\
\hline Succinic $\left(\mathrm{mg} \mathrm{L}^{-1}\right)$ & $163 \pm 32^{b}$ & ND & $313 \pm 86^{a}$ & $173 \pm 20^{\mathrm{b}}$ & $153 \pm 75^{\mathrm{b}}$ & $203 \pm 25^{\mathrm{ab}}$ \\
\hline Acetic $\left(\mathrm{mg} \mathrm{L}^{-1}\right)$ & $447 \pm 23^{a}$ & $360 \pm 95^{a}$ & $440 \pm 36^{\mathrm{a}}$ & $433 \pm 73^{\mathrm{a}}$ & $437 \pm 92^{\mathrm{a}}$ & $347 \pm 32^{\mathrm{a}}$ \\
\hline Total Organic acids $\left(\mathrm{g} \mathrm{L}^{-1}\right)$ & $8.64 \pm 0.16$ & $12.04 \pm 0.47$ & $9.58 \pm 0.36$ & $9.40 \pm 0.25$ & $8.82 \pm 0.43$ & $9.01 \pm 0.17$ \\
\hline
\end{tabular}

Means followed by the same letters in the same lines do not differ by Tukey test at 5\% probability.

AT - expressed as g $100 \mathrm{~mL}^{-1}$ tartaric acid; SS - expressed as\% ( ${ }^{\circ}$ Brix). ND - not detected.

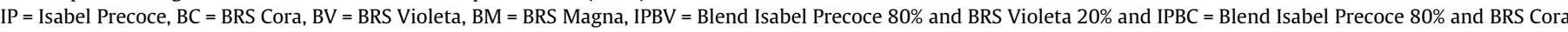
$20 \%$.

colour and also the concentration of total acidity. This was found to be the case in our study since the juice IPBC presented significantly higher values for TA and tartaric acid and malic acid concentrations in relation to the juice IP.

Under the tropical conditions of the viticulture carried out in the Sub-middle SFV, due to the production scheduled for different grape pruning dates, it is possible to harvest grapes at different maturation stages simultaneously. Thus, a mixture of grapes with different concentrations of SS and TA can be obtained, which is advantageous in relation to obtaining standardized juices in relation to the sugars and acidity, important quality parameters which affect the flavor in grape juices.

\subsection{Total phenolics and flavanols compounds}

The mean values and standard deviations for the contents of total phenolic compounds and flavanols of the juices are shown in Table 2. The phenolic compounds concentrations showed significant differences between the cultivars studied. The juice BV presented the highest mean value $\left(2712 \mathrm{mg} \mathrm{L}^{-1}\right)$, followed by

Table 2

Phenolic compounds of juices from new cultivars of Brazilian grapes planted in the São Francisco's Valley, Petrolina - PE.

\begin{tabular}{|c|c|c|c|c|c|c|}
\hline \multirow[t]{2}{*}{ Flavanols } & \multicolumn{6}{|l|}{ Juice } \\
\hline & IP & $\mathrm{BC}$ & BV & $\mathrm{BM}$ & IPBV & IPBC \\
\hline$(+)$-Catechin & $4.7 \pm 0.1^{\mathrm{c}}$ & $12.4 \pm 0.3^{\mathrm{b}}$ & $19.8 \pm 0.4^{\mathrm{a}}$ & $9.1 \pm 3.0^{b}$ & $21.0 \pm 0.1^{\mathrm{a}}$ & $17.9 \pm 0.1^{\mathrm{a}}$ \\
\hline (-)-Epicatechin & $1.0 \pm 1.0^{\mathrm{a}}$ & $1.4 \pm 0.5^{\mathrm{a}}$ & $0.6 \pm 0.1^{\mathrm{a}}$ & $1.3 \pm 0.1^{\mathrm{a}}$ & $0.8 \pm 0.8^{\mathrm{a}}$ & $1.7 \pm 0.3^{\mathrm{a}}$ \\
\hline (-)-Epicatechin gallate & $1.6 \pm 0.1^{\mathrm{a}}$ & $1.2 \pm 0.0^{\mathrm{b}}$ & $1.9 \pm 0.2^{\mathrm{a}}$ & $1.3 \pm 0.1^{\mathrm{a}}$ & $0.8 \pm 0.2^{c}$ & $0.7 \pm 0.2^{c}$ \\
\hline (-)-Epigallocatechin & $0.9 \pm 0.1^{\mathrm{e}}$ & $4.7 \pm 0.4^{b}$ & $6.2 \pm 0.1^{\mathrm{a}}$ & $4.2 \pm 0.2^{\mathrm{cb}}$ & $4.0 \pm 0.1^{c}$ & $2.4 \pm 0.1^{d}$ \\
\hline Procyanidin A2 & $2.8 \pm 0.2^{\mathrm{bc}}$ & $2.9 \pm 0.2^{b}$ & $3.6 \pm 0.1^{\mathrm{a}}$ & $2.3 \pm 0.1^{\mathrm{c}}$ & $1.7 \pm 0.4^{\mathrm{d}}$ & $1.4 \pm 0.1^{\mathrm{d}}$ \\
\hline Procyanidin B1 & $47.1 \pm 0.1^{\mathrm{b}}$ & $37.2 \pm 0.6^{\mathrm{e}}$ & $44.2 \pm 0.3^{c}$ & $36.0 \pm 0.7^{f}$ & $69.4 \pm 0.1^{\mathrm{a}}$ & $38.5 \pm 0.1^{\mathrm{d}}$ \\
\hline Procyanidin B2 & $14.3 \pm 0.1^{\mathrm{c}}$ & $16.3 \pm 0.7^{\mathrm{b}}$ & $17.5 \pm 0.5^{\mathrm{a}}$ & $17.9 \pm 0.4^{\mathrm{a}}$ & $13.1 \pm 0.3^{\mathrm{d}}$ & $10.9 \pm 0.2^{\mathrm{e}}$ \\
\hline Total Flavanols quantification & $72.4 \pm 1.7$ & $76.1 \pm 2.7$ & $93.8 \pm 1.7$ & $72.1 \pm 4.6$ & $110.8 \pm 2.0$ & $73.5 \pm 1.1$ \\
\hline \multicolumn{7}{|l|}{ Anthocyanins } \\
\hline Malvidin 3,5-diglucoside & $1.8 \pm 0.0^{\mathrm{d}}$ & $0.7 \pm 0.0^{\mathrm{e}}$ & $11.7 \pm 0.0^{\mathrm{a}}$ & $5.5 \pm 0.2^{\mathrm{b}}$ & $4.7 \pm 0.1^{c}$ & $4.8 \pm 0.1^{\mathrm{c}}$ \\
\hline Malvidin 3-glucoside & $0.9 \pm 0.1^{\mathrm{d}}$ & ND & $1.6 \pm 0.2^{\mathrm{b}}$ & $1.3 \pm 0.3^{\mathrm{c}}$ & $1.6 \pm 0.1^{\mathrm{b}}$ & $6.2 \pm 0.1^{\mathrm{a}}$ \\
\hline Cyanidin-3,5-diglucoside & ND & $11.8 \pm 0.1^{\mathrm{c}}$ & $38.0 \pm 0.6^{\mathrm{a}}$ & $12.6 \pm 0.1^{\mathrm{b}}$ & $9.2 \pm 0.1^{\mathrm{d}}$ & $4.3 \pm 0.2^{\mathrm{e}}$ \\
\hline Cyanidin 3-glucoside & $3.0 \pm 0.0^{\mathrm{e}}$ & $1.4 \pm 0.1^{\mathrm{f}}$ & $32.7 \pm 0.5^{\mathrm{b}}$ & $37.2 \pm 0.2^{\mathrm{a}}$ & $10.7 \pm 0.1^{\mathrm{c}}$ & $7.8 \pm 0.1^{\mathrm{d}}$ \\
\hline Delphinidin 3-glucoside & ND & $11.7 \pm 0.2^{\mathrm{d}}$ & $73.7 \pm 1.2^{\mathrm{a}}$ & $52.2 \pm 0.4^{\mathrm{b}}$ & $15.2 \pm 0.2^{c}$ & $3.0 \pm 0.1^{\mathrm{e}}$ \\
\hline Peonidin 3-glucoside & $0.2 \pm 0.1^{\mathrm{c}}$ & $0.3 \pm 0.1^{\mathrm{c}}$ & $0.2 \pm 0.0^{c}$ & ND & $0.4 \pm 0.0^{\mathrm{b}}$ & $1.5 \pm 0.1^{\mathrm{a}}$ \\
\hline Pelargonidin 3-glucoside & ND & $6.7 \pm 0.1^{\mathrm{a}}$ & $6.7 \pm 0.1^{\mathrm{a}}$ & $6.6 \pm 0.1^{\mathrm{a}}$ & $1.2 \pm 0.2^{\mathrm{b}}$ & $0.5 \pm 0.1^{\mathrm{a}}$ \\
\hline Total anthocyanin quantification & $5.9 \pm 0.2$ & $30.6 \pm 0.6$ & $164.6 \pm 2.6$ & $115.4 \pm 1.3$ & $43 \pm 0.8$ & $28.1 \pm 0.8$ \\
\hline \multicolumn{7}{|l|}{ Phenolic acids } \\
\hline Gallic acid & $1.8 \pm 0.1^{\mathrm{e}}$ & $13.6 \pm 0.1^{\mathrm{a}}$ & $10.5 \pm 0.8^{\mathrm{b}}$ & $7.3 \pm 0.1^{\mathrm{c}}$ & $6.4 \pm 0.4^{\mathrm{c}}$ & $3.9 \pm 0.1^{\mathrm{d}}$ \\
\hline Caffeic acid & $8.6 \pm 0.1^{\mathrm{d}}$ & $35.8 \pm 0.5^{\mathrm{a}}$ & $28.9 \pm 0.4^{\mathrm{b}}$ & $41.2 \pm 6.0^{\mathrm{a}}$ & $23.3 \pm 0.1^{\mathrm{bc}}$ & $18.8 \pm 0.2^{\mathrm{b}}$ \\
\hline Cinnamic acid & $0.5 \pm 0.0^{\mathrm{d}}$ & $0.6 \pm 0.2^{\mathrm{d}}$ & $1.9 \pm 0.1^{\mathrm{b}}$ & $2.8 \pm 0.1^{\mathrm{a}}$ & $0.4 \pm 0.0^{\mathrm{d}}$ & $1.6 \pm 0.0^{c}$ \\
\hline Chlorogenic acid & $4.1 \pm 0.1^{\mathrm{d}}$ & $8.3 \pm 0.3^{b}$ & $21.3 \pm 0.6^{\mathrm{a}}$ & $2.1 \pm 0.1^{\mathrm{e}}$ & $4.8 \pm 0.1^{\mathrm{c}}$ & $4.8 \pm 0.2^{\mathrm{c}}$ \\
\hline$p$-Coumaric acid & $2.6 \pm 0.1^{\mathrm{d}}$ & $4.5 \pm 0.4^{\mathrm{bc}}$ & $9.0 \pm 0.1^{\mathrm{a}}$ & $5.1 \pm 1.0^{\mathrm{b}}$ & $3.8 \pm 0.0^{c}$ & $2.1 \pm 0.0^{\mathrm{d}}$ \\
\hline Total phenolics acids quantification & $17.6 \pm 0.4$ & $62.8 \pm 1.5$ & $71.6 \pm 1.9$ & $58.5 \pm 7.3$ & $37.6 \pm 0.6$ & $31.2 \pm 0.5$ \\
\hline Total monomeric anthocyanins $^{\dagger}$ & $29 \pm 1^{\mathrm{f}}$ & $225 \pm 1^{\mathrm{c}}$ & $464 \pm 6^{a}$ & $410 \pm 2^{b}$ & $156 \pm 2^{\mathrm{d}}$ & $127 \pm 2^{\mathrm{e}}$ \\
\hline Total Phenolics ${ }^{\S}$ & $779 \pm 27^{d}$ & $1944 \pm 16^{\mathrm{b}}$ & $2712 \pm 3^{\mathrm{a}}$ & $2097 \pm 66^{\mathrm{b}}$ & $1897 \pm 169^{b}$ & $1353 \pm 23^{c}$ \\
\hline
\end{tabular}

Means followed by the same letters in the same lines do not differ by Tukey test at 5\% probability. ND - not detected.

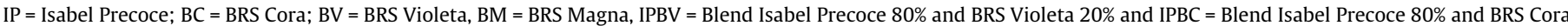
$20 \%$.

$\dagger$ Total monomeric anthocyanins quantified by the technic of difference of pH and expressed as equivalent to cyanidin 3-glucoside.

$\S$ Total ohenolics measured with Folin-Ciocateau expressed as $\mathrm{mg} \mathrm{L}^{-1}$ equivalent to gallic acid. 
BM (2097 $\mathrm{mg} \mathrm{L}^{-1}$ ) and BC (1944 $\left.\mathrm{mg} \mathrm{L}^{-1}\right)$. The juice IP showed the lowest concentration of total phenolic compounds $\left(779 \mathrm{mg} \mathrm{L}^{-1}\right)$, while for IPBV and IPBC the concentrations were higher (1897 and $1353 \mathrm{mg} \mathrm{L}^{-1}$, respectively). According to the literature, the total phenolic compounds concentrations in commercial grape juices in Brazil varies from 270 to $3433 \mathrm{mg} \mathrm{L}^{-1}$, with mean values of between 1430 and $1915 \mathrm{mg} \mathrm{L}^{-1}$, these differences being mainly due to the production techniques and to the particular characteristics of the region (Burin et al., 2010; Malacrida \& Motta, 2005; Sautter et al., 2005). In commercial Spanish juices, Dávalos et al. (2005) reported values of 705 to $1177 \mathrm{mg} \mathrm{L}^{-1}$, while the values for juices produced from the varieties Noble ( $V$. rotundifolia) and Concord (V. labrusca) varied from 1280 to $2880 \mathrm{mg} \mathrm{L}^{-1}$, respectively (Iyer et al., 2010; Talcott \& Lee, 2002).

The juices produced showed significant differences in relation to the flavanol content. The flavanol found in greatest quantity was procyanidin $\mathrm{B} 1$, followed by procyanidin $\mathrm{B} 2$ and catechin. The juice IP presented the highest concentration of procyanidin B1 (47.1 $\mathrm{mg} \mathrm{L}^{-1}$ ) and the lowest concentrations of catechin (4.7 $\left.\mathrm{mg} \mathrm{L}^{-1}\right)$ and epigalocatechin $\left(0.9 \mathrm{mg} \mathrm{L}^{-1}\right)$. The juice BV contained the highest concentrations of catechin $\left(19.4 \mathrm{mg} \mathrm{L}^{-1}\right)$, epicatechin gallate (6.2 $\mathrm{mg} \mathrm{L}^{-1}$ ) and procyanidin A2 (3.6 $\left.\mathrm{mg} \mathrm{L}^{-1}\right)$, as well as the highest total value for the flavanols quantified $\left(93.8 \mathrm{mg} \mathrm{L}^{-1}\right)$. IPBV and IPBC presented a significantly higher concentration of catechin and epigalocatechin gallate in comparison with IP.

In the characterization of phenolic compounds in artisanal juices extracted in a steam pan from grapes of Isabel Precoce, BRS Cora and BRS Violeta grown in SFV, Natividade et al. (2013) obtained higher values for catechin, procyanidin B2 and epicatechin in the BRS Violeta juices than those found in this study. However, in the case of procyanidin B1, Natividade et al. (2013) found lower values than those reported herein. For juices produced from grapes of the variety Concord applying a hot-pressing (HP) process in Portugal, the values for catechin, epicatechin and procyanidin B2 were similar to those found in this study, but the procyanidin B1 values were lower (Fuleki \& Ricardo-da-Silva, 2003). In commercial juices produced from grapes of the variety Bordô (V. labrusca) managed in a traditional system and in an organic system in Rio Grande do Sul State, Brazil, the values for procyanidins B1 and B2 were lower than those obtained in this study (Dani et al., 2007). Based on these results it can be observed that the different preparation techniques, processing conditions, cultural practises and grape varieties used in the production of juices results in products with different flavanol and phenolic compositions. The juices BV, BC and BM contained high concentrations of total phenolics, and IPBV and IPBC showed significantly higher levels of phenolic compounds than IP. The juice BV had the highest values for the total flavanols quantified and the total phenolic compounds. In all of the juices (IP, BC, BV and BM) the main flavanol found was procyanidin B1, with higher mean values than those found in the literature for grape juices.

\subsection{Monomeric and glycosylated anthocyanins}

The mean values obtained for anthocyanins are shown in Table 2 . The mean values for the monomeric anthocyanins content of the juices varied from $29 \mathrm{mg} \mathrm{L}^{-1}$ to $464 \mathrm{mg} \mathrm{L}^{-1}$. The juice BV presented the highest mean value for monomeric anthocyanins (464 $\left.\mathrm{mg} \mathrm{L}^{-1}\right)$, followed in decreasing order by BM $\left(410 \mathrm{mg} \mathrm{L}^{-1}\right)$, BV (225 mg L $\left.{ }^{-1}\right)$ and IP ( $\left.29 \mathrm{mg} \mathrm{L}^{-1}\right)$ while the juices IPBV and IPBC obtained values of 157 and $126 \mathrm{mg} \mathrm{L}^{-1}$, respectively. The monomeric anthocyanin values obtained for the juices analysed in this study are in agreement with those reported in the literature for artisanal juices and Brazilian commercial juices, which range from 25.6 to $450.4 \mathrm{mg} \mathrm{L}^{-1}$ (Burin et al., 2010; Malacrida \& Motta, 2005).
By way of comparison, in the HPLC analysis the main anthocyanins found were delphinidin 3-glucoside and the cyanidins 3,5diglucoside and 3-monoglucoside. The juice that presented the highest anthocyanin content according to the HPLC analysis was BV (164.6 $\left.\mathrm{mg} \mathrm{L}^{-1}\right)$, followed by BM (115.4 $\left.\mathrm{mg} \mathrm{L}^{-1}\right)$, and the juices IP and BC showed values of 5.9 and $30.6 \mathrm{mg} \mathrm{L}^{-1}$, respectively. The overall contents of anthocyanins in IPBV and IPBC were 43 and $28.1 \mathrm{mg} \mathrm{L}^{-1}$, respectively, showing significantly higher levels compared with IP. The juices BV and BM notably contained higher concentrations of delphinidin 3-glucoside (72.7 and $52.2 \mathrm{mg} \mathrm{L}^{-1}$, respectively) while $\mathrm{BC}$ had the same concentration for delphinidin 3 -glucoside and cyanidin 3,5-diglucoside $\left(11.8 \mathrm{mg} \mathrm{L}^{-1}\right)$. The predominance of delphinidin and cyanidins was observed for IPBV while in IPBC malvidins and cyanidins were the main anthocyanins present.

The anthocyanin profile differed according to the grape variety. In juices produced from grapes of Concord and Salvador (hybrid Vitis vinifera $\times$ Vitis rupestres) the predominant anthocyanins were, in decreasing order: malvidin 3-glucoside, delphinidin 3-glucoside and petunidin 3-glucoside, and in the juice of Rubired (hybrid $V$. vinifera $\times V$. rupestres) malvidin 3,5-diglucoside and peonidin 3,5diglucoside predominated (Wang, Race, \& Shrikhande, 2003). The artisanal juices made from the varieties Isabel Precoce, BRS Cora and BRS Violeta (Natividade et al., 2013) showed anthocyanin profiles similar to those observed in this study, considering that the main anthocyanins found in the juice samples were delphinidin 3-glucoside in BC and BV, and malvidin in IP. However, the sum of the anthocyanins quantified was higher, varying from $73 \mathrm{mg} \mathrm{L}^{-1}$ in IP to $666.8 \mathrm{mg} \mathrm{L}^{-1}$ in BV. It is important to note that in the artisanal preparation of juices in a steam pan the grapes pass through an aggressive heating process with extraction temperatures of up to $80^{\circ} \mathrm{C}$, which can lead to degradation of the thin coating layer and the thermal degradation of anthocyanins. Therefore, the extraction of phenolic compounds occurs to a different extent in comparison with the industrial processing investigated in this study, in which the temperature of extraction was $60^{\circ} \mathrm{C}$ using an enzymatic preparation based on pectinases, without pressing of the bagasse.

\subsection{Phenolic acids}

The values obtained for the phenolic acids of the juice samples are reported in Table 2 and the concentrations varied from 1.8 to 13.6 for gallic acid, 8.6 to 41.2 for caffeic acid, 2.1 to 21.3 for chlorogenic acid, 2.1 to 9.0 for $p$-coumaric acid and 0.4 to $2.8 \mathrm{mg} \mathrm{L}^{-1}$ for cinnamic acid. The juices BC, BV and BM had higher concentrations of phenolic acids than IP. The juice BV had the highest concentration of chlorogenic acid $\left(21.3 \mathrm{mg} \mathrm{L}^{-1}\right)$ while $\mathrm{BM}$ and $\mathrm{BC}$ had the highest concentrations of caffeic acid $\left(41.2\right.$ and $35.8 \mathrm{mg} \mathrm{L}^{-1}$, respectively). The juices IPBV and IPBC had higher concentrations of gallic, caffeic and chlorogenic acid in comparison with IP, with caffeic acid being the main phenolic acid present in the juices analysed.

In a study reported in the literature, artisanal juices of IP, BC and BV originating from SFV showed lower values for phenolic acids than those obtained in this study, the highest concentrations being 7.3 and $2.6 \mathrm{mg} \mathrm{L}^{-1}$ for caffeic and chlorogenic acid, respectively, for IP (Natividade et al., 2013). In a commercial juice of Concord, Stalmach, Edwards, Wightman, and Crozier (2011) observed concentrations of $8.6,0.3$ and $0.9 \mathrm{mg} \mathrm{L}^{-1}$ for gallic acid, caffeic acid and $p$-coumaric acid, respectively. In 100 samples of red and white wines the highest values obtained for phenolic acids were $72.0 \mathrm{mg} \mathrm{L}^{-1}$ for gallic acid, $23.0 \mathrm{mg} \mathrm{L}^{-1}$ for caffeic acid, $10.7 \mathrm{mg} \mathrm{L}^{-1}$ for $p$-coumaric acid and $3.7 \mathrm{mg} \mathrm{L}^{-1}$ for chlorogenic acid (Granato, Katayama, \& Castro, 2011; Robbins \& Bean, 2004). 
The values for caffeic, $p$-coumaric and chlorogenic acids obtained for the juices prepared in this study can be considered to be high, and for caffeic and chlorogenic acids the values were higher than the maximum concentrations observed in many wines (Granato et al., 2011; Robbins \& Bean, 2004).

\subsection{Flavonols and trans-resveratrol}

The values obtained for flavonols and $t$-resveratrol are presented in Fig. 1. The juice samples showed significant differences between the varieties and blends (IPBC and IPBV) analysed, with concentrations varying from 0.5 to $1.0 \mathrm{mg} \mathrm{L}^{-1}$ for kaempferol, $0.5-0.8 \mathrm{mg} \mathrm{L}^{-1}$ for quercetin, $0.3-1.7 \mathrm{mg} \mathrm{L}^{-1}$ for isorhamnetin, $0.9-5.9 \mathrm{mg} \mathrm{L}^{-1}$ for rutin and $0.1-0.8 \mathrm{mg} \mathrm{L}^{-1}$ for myricetin. Of the flavonols quantified, rutin was presented in highest concentrations in the juices BM and BV, with mean values of 5.9 and $4.7 \mathrm{mg} \mathrm{L}^{-1}$, respectively. For kaempferol there was no significant difference between the juices; however, for myricetin and isorhamnetin BV had the highest concentrations ( 0.8 and $1.2 \mathrm{mg} \mathrm{L}^{-1}$, respectively). The juice IP had the highest concentration of quercetin $\left(0.8 \mathrm{mg} \mathrm{L}^{-1}\right)$ and the lowest of rutin $\left(0.9 \mathrm{mg} \mathrm{L}^{-1}\right)$ and myricetin $\left(0.1 \mathrm{mg} \mathrm{L}^{-1}\right)$. IPBV and IPBC had significantly higher concentrations of rutin, isorhamnetin and myricetin in comparison with the juice IP.

In the characterization of artisanal juices made from grapes of the cultivars IP, BC and BM originating from the SFV, Natividade et al. (2013) found flavonol values similar to those obtained in this study, while rutin was the main flavonol detected in the juice BV (5.1 $\mathrm{mg} \mathrm{L}^{-1}$ ). In juices produced from grapes of the varieties Carlos (white) and Noble (red), Talcott and Lee (2002) obtained mean values varying from 0.6 to 50.5 for myricetin, 1.8-24.3 for quercetin and 1.9-26.1 $\mathrm{mg} \mathrm{L}^{-1}$ for kaempferol.

The myricetin, quercetin and kaempferol values for the juices studied are similar to those obtained by Natividade et al. (2013) for artisanal juices produced from the same varieties grown in the SFV, and lower than those reported in the literature for juices produced from other varieties in other regions (Stalmach et al. 2011; Talcott \& Lee, 2002). The concentrations of rutin observed in the juices BM and BV are considered to be high, since in $73 \mathrm{com}$ mercial red wines produced from $V$. vinifera grapes originating from Brazil, Argentina and Chile, the rutin concentrations were found to vary from 0.83 to $4.19 \mathrm{mg} \mathrm{L}^{-1}$ (Granato et al., 2011). The juices IPBC and IPBC showed significantly higher concentrations of flavonols (mainly rutin) compared to IP. It is known that the biosynthesis process involved in the production of flavonols in plant tissues is influenced by solar light, and grapes with a high exposure to daylight show a significant increase in the biosynthesis of flavonols (Spayd, Tarara, Mee, \& Ferguson, 2002). However, the juices in this study, produced from grapes grown in the SFV, showed lower concentrations of myricetin, quercetin and kaempferol than those reported in the literature, despite the high temperatures and luminosity typical of the climate in the SFV. In the case of rutin, the concentrations found in juices BM and BV are considered to be high, which suggests that these cultivars might possess intrinsic characteristics that benefit the synthesis of this flavanol.

With regard to the values for the trans-resveratrol content, the variations in the juices studied were significant. The juice BV had the greatest concentration of $t$-resveratrol $\left(1.10 \mathrm{mg} \mathrm{L}^{-1}\right)$, followed by IP $\left(0.63 \mathrm{mg} \mathrm{L}^{-1}\right)$ and then $\mathrm{BC}$ and $\mathrm{BM}$, which both had $0.40 \mathrm{mg} \mathrm{L}^{-1}$. In the case of the juices IPBV and IPBC, the variety $\mathrm{BV}$ had a significant influence, increasing the concentration from $0.63 \mathrm{mg} \mathrm{L}^{-1}$ in IP to $0.77 \mathrm{mg} \mathrm{L}^{-1}$ in IPBV, while IPBC maintained the $t$-resveratrol concentration of $0.40 \mathrm{mg} \mathrm{L}^{-1}$ from the juice IP. For artisanal juices of the varieties IP, BC and BV originating from the SFV, Natividade et al. (2013) found $t$-resveratrol concentrations varying from $0.05 \mathrm{mg} \mathrm{L}^{-1}$ for IP to $0.40 \mathrm{mg} \mathrm{L}^{-1}$ for $\mathrm{BV}$, with nondetectable levels in BC. Dani et al. (2007) obtained $t$-resveratrol concentrations varying from 0.08 to $0.21 \mathrm{mg} \mathrm{L}^{-1}$ in commercial juices of "Bordô" produced from grapes cultivated in conventional





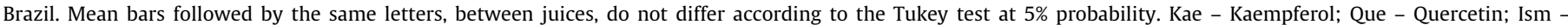

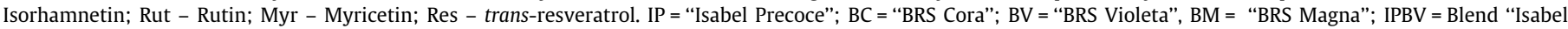
Precoce" $80 \%$ and "BRS Violeta" 20\% and IPBC = Blend "Isabel Precoce" $80 \%$ and "BRS Cora" $20 \%$. 
and organic systems, respectively. For Brazilian grape juices, Sautter et al. (2005) reported values from 0.39 to $0.44 \mathrm{mg} \mathrm{L}^{-1}$ for $t$-resveratrol. In a study carried out by Leblanc et al. (2008) on the influence of different production techniques on the stilbenes concentration in juices produced from Noble and Carlos (Vitis roduntifolia) and Mid-South and Miss Blanc (V. labrusca) grapes it was verified that with the HP process the highest stilbene concentrations was obtained, and that $t$-resveratrol was detected only in the juices produced from Carlos and Noble grapes using this technique, in concentrations of approximately $0.10 \mathrm{mg} \mathrm{L}^{-1}$.

Studies on resveratrol are of great interest considering the health benefits for consumers. Thus, it is important to note the high concentrations of $t$-resveratrol in the juices studied, mainly in $\mathrm{BV}$, with the concentrations observed being higher than those reported in the literature for several different grape juices. However, the $t$-resveratrol values reported herein are similar to those found in wines originating from the same region, for which values varied between 0.21 and $1.26 \mathrm{mg} \mathrm{L}^{-1}$ in most samples analysed (Lucena et al., 2010). It has been noted by Lucena et al. (2010) that most of the resveratrol present in wines originating from São Francisco Valley was in the form of the isomer cis-resveratrol, and in most cases values were between 1.06 and $5.49 \mathrm{mg} \mathrm{L}^{-1}$. Other authors have also reported that resveratrol is present in wines predominantly in the form cis-resveratrol (Vitrac et al., 2005). Similar findings were also reported by Leblanc et al. (2008) for juices produced from Carlos and Noble grapes using different processing techniques, which suggests that the resveratrol concentrations in the juices studied could be even higher than those obtained.

The quantity of resveratrol in grapes, wines and juices varies depending on factors such as the weather, grape variety and fungal infection, since this stilbene is produced as part of the defence mechanism of plants. The exposure to UV light and the enological practises also strongly influence in the grape composition (Ali et al., 2010). Factors such as high solar light exposure and high temperatures, characteristic conditions in the SFV, or the grape management techniques (e.g., submission of plants to hydric stress by restricting irrigation after "verasion") could also be associated with the presence of higher resveratrol concentrations in the grapes and, as a consequence, derivatives such as juice (Lucena et al., 2010).

\subsection{Antioxidant activity}

The means and the standard deviations of the results obtained are shown in Fig. 2. The antioxidant activity (AOX) of the juices was expressed as equivalents of Trolox per litre of juice $\left(\mathrm{mM} \mathrm{TEAC} \mathrm{L}^{-1}\right.$ ). On applying the DPPH method, significant differences between the juice IP and the juices IPBC and IPBV were observed. IP presented lower AOX (mean value of $11.5 \mathrm{mM}$ ) compared with the juices BC, BV and BM (mean values of $44.2 ; 51.6$ and $49.2 \mathrm{mM}$, respectively). The juices IPBV and IPBC showed activities of 37.3 and $31.0 \mathrm{mM}$, respectively. In the case of the ABTS method, only IP showed a significant difference in relation to the AOX, with a mean value of $18.2 \mathrm{mM}$. The juices $\mathrm{BC}, \mathrm{BV}$ and $\mathrm{BM}$ had mean values of 51.0, 54.6 and 54.2 mM, respectively. For IPBC and IPBV the values for the antioxidant activity were 49.4 and $45.6 \mathrm{mM}$, respectively.

The AOX of commercial and artisanal grape juices, measured using the DPPH and ABTS methods, found in the literature vary from 2.51 to $11.05 \mathrm{mM} \mathrm{TEAC}^{-1}$ (Burin et al., 2010) and for wines the values reported range between 3.44 and $23.17 \mathrm{mM} \mathrm{TEAC} \mathrm{L}^{-1}$ (Gris et al., 2011).

The antioxidant capacity measured using the DPPH and ABTS methods for all juices studied showed high values. The juice IP showed a lower AOX compared with BC, BV and BM which had much higher antioxidant capacity values than those found in the

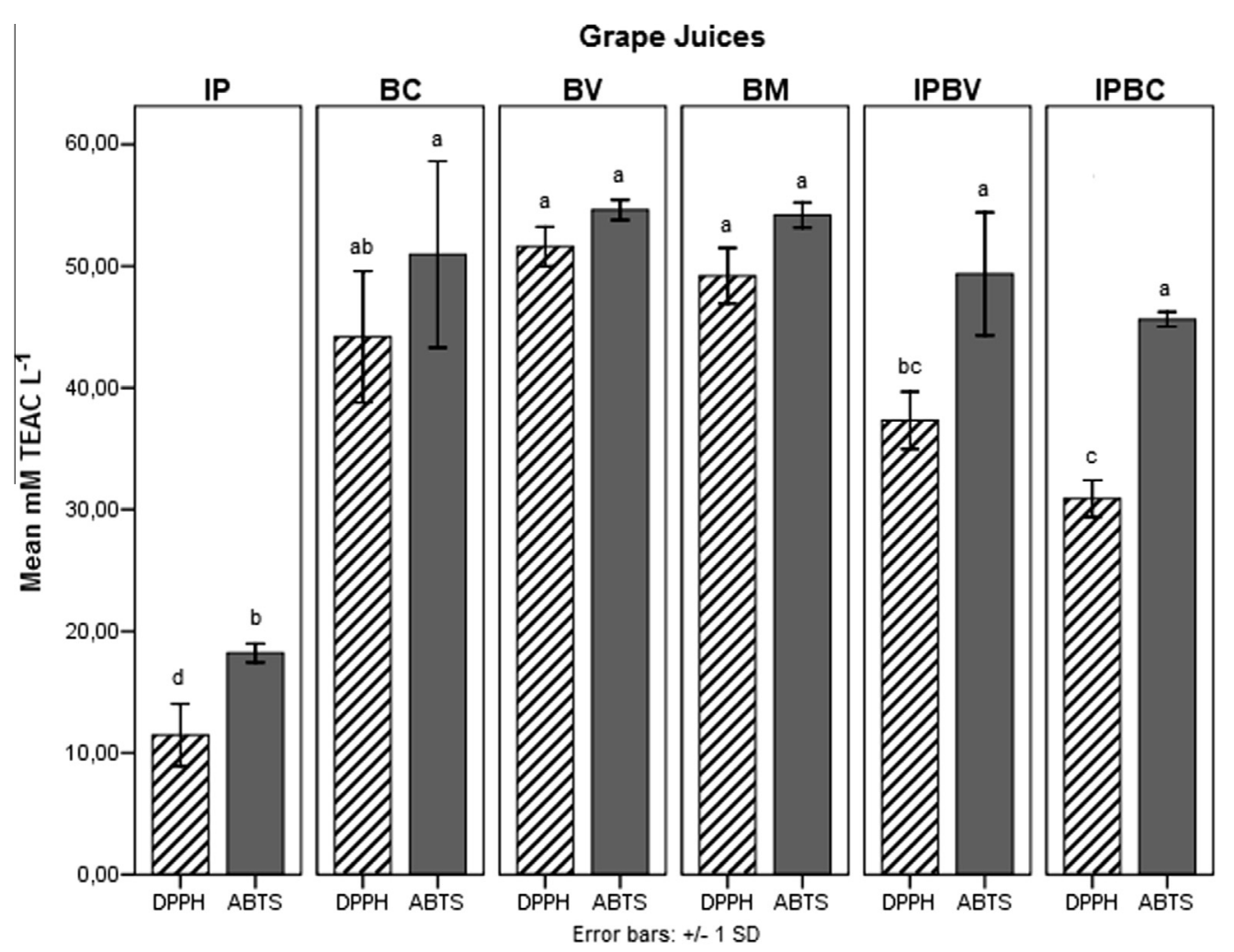

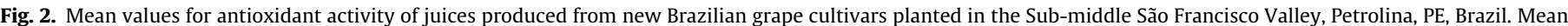

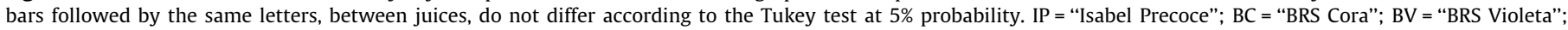
BM = "BRS Magna"; IPBV = Blend "Isabel Precoce" 80\% and "BRS Violeta" 20\% and IPBC = Blend "Isabel Precoce" $80 \%$ end "BRS Cora" $20 \%$. 
Table 3

Results of Pearson's correlation analysis between quantification of phenolic compounds and antioxidant activity of juices measured by DPPH and ABTS methods.

\begin{tabular}{|c|c|c|c|c|}
\hline \multirow[t]{2}{*}{ Flavanols } & \multicolumn{2}{|l|}{ DPPH } & \multicolumn{2}{|l|}{ ABTS } \\
\hline & Pearson $r$ & $p$-Values & Pearson $r$ & $p$-Values \\
\hline$(+)$-Catechin & $0.47^{\mathrm{a}}$ & 0.049 & $0.60^{\mathrm{b}}$ & 0.009 \\
\hline (-)-Epicatechin & 0.07 & 0.773 & -0.18 & 0.485 \\
\hline (-)-Epicatechin gallate & $0.92^{\mathrm{b}}$ & 0.000 & $0.83^{\mathrm{b}}$ & 0.000 \\
\hline (-)-Epigallocatechin & -0.07 & 0.796 & -0.03 & 0.910 \\
\hline Procyanidin A2 & 0.24 & 0.336 & -0.01 & 0.980 \\
\hline Procyanidin B1 & -0.19 & 0.442 & -0.11 & 0.678 \\
\hline Procyanidin B2 & $0.60^{\mathrm{b}}$ & 0.008 & 0.31 & 0.211 \\
\hline \multicolumn{5}{|l|}{ Flavonols } \\
\hline Kaempferol & -0.05 & 0.857 & -0.04 & 0.884 \\
\hline Isorhamnetin & -0.34 & 0.171 & -0.16 & 0.524 \\
\hline Rutin & $0.74^{\mathrm{b}}$ & 0.000 & $0.61^{\mathrm{b}}$ & 0.008 \\
\hline Quercetin & $-0.69^{\mathrm{b}}$ & 0.001 & $-0.81^{\mathrm{b}}$ & 0.000 \\
\hline Myricetin & $0.76^{\mathrm{b}}$ & 0.000 & $0.69^{\mathrm{b}}$ & 0.002 \\
\hline \multicolumn{5}{|l|}{ Stilbene } \\
\hline trans-resveratrol & 0.15 & 0.541 & 0.09 & 0.723 \\
\hline \multicolumn{5}{|l|}{ Phenolic acids } \\
\hline Gallic acid & $0.78^{\mathrm{b}}$ & 0.000 & $0.69^{\mathrm{b}}$ & 0.002 \\
\hline Caffeic acid & $0.86^{\mathrm{b}}$ & 0.000 & $0.79^{\mathrm{b}}$ & 0.000 \\
\hline Cinnamic acid & $0.56^{\mathrm{a}}$ & 0.015 & $0.48^{\mathrm{a}}$ & 0.045 \\
\hline Chlorogenic acid & 0.46 & 0.055 & 0.33 & 0.178 \\
\hline p-Coumaric acid & $0.73^{b}$ & 0.001 & $0.53^{\mathrm{a}}$ & 0.025 \\
\hline \multicolumn{5}{|l|}{ Anthocyanins } \\
\hline Pelargonidin 3-glucoside & $0.84^{\mathrm{b}}$ & 0.000 & $0.67^{\mathrm{b}}$ & 0.003 \\
\hline Cyanidin 3-glucoside & $0.74^{\mathrm{b}}$ & 0.001 & $0.59^{\mathrm{a}}$ & 0.010 \\
\hline Cyanidin 3,5-diglucoside & $0.67^{\mathrm{b}}$ & 0.003 & $0.54^{\mathrm{a}}$ & 0.022 \\
\hline Malvidin 3-glucoside & $0.54^{\mathrm{a}}$ & 0.020 & $0.47^{\mathrm{a}}$ & 0.047 \\
\hline Delphinidin 3-glucoside & $0.76^{\mathrm{b}}$ & 0.000 & $0.60^{\mathrm{b}}$ & 0.009 \\
\hline Malvidina 3,5-diglucoside & -0.16 & 0.523 & 0.05 & 0.849 \\
\hline Peonidin 3-glucoside & -0.28 & 0.257 & -0.03 & 0.910 \\
\hline Total monomeric anthocyanins & $0.89^{\mathrm{b}}$ & 0.000 & $0.74^{\mathrm{b}}$ & 0.000 \\
\hline Total phenolics & $0.94^{\mathrm{b}}$ & 0.000 & $0.84^{\mathrm{b}}$ & 0.000 \\
\hline DPPH & - & - & $0.88^{\mathrm{b}}$ & 0.000 \\
\hline
\end{tabular}

a Significant correlations at $5 \%$ probability of error $(p<0.05)$.

b Significant correlations at $1 \%$ probability of error $(p<0.01)$.

literature. The juices IPBC and IPBV obtained significantly higher AOX values in comparison with IP, which emphasises the importance of using these juices, not only for improved colour but also to increase the phenolic compounds concentration and the AOX of juices produced with "Isabel Precoce", which is the major grape planted in the SFV. Of the methods used for the determination of the AOX, the DPPH method showed the greatest differentiation capacity of the results obtained.

The Pearson correlation coefficients obtained for the data on the phenolic compounds and antioxidant activity (DPPH and ABTS) are presented in Table 3. For discussion purposes the positive correlation coefficients are considered, with significance set at $1 \%$ probability of error, for the data on all of the phenolic compounds determined and the antioxidant capacity.

On applying the DPPH method, the phenolic compounds that showed positive values for $r(p<0.01)$ were the flavanols epicatechin gallate $(r=0.92)$ and procyanidin B2 $(r=0.60)$, rutin $(r=0.74)$ and myricetin $(r=0.76)$, the phenolic acids gallic $(r=0.78)$, caffeic $(r=0.86)$ and $p$-coumaric $(r=0,73)$, and the anthocyanins pelargonidin 3-diglucoside $(r=0.84)$, cyanidin 3-diglucoside $(r=0.74)$, cyanidin 3,5-diglucoside $(r=0.67)$ and delphinidin 3-diglucoside $(r=0.76)$.

In the case of the ABTS method, the phenolic compounds that showed positive values for $r(p<0.01)$ were the flavanols catechin $(r=0.60)$ and epicatechin gallate $(r=0.83)$, rutin $(r=0.61)$ and myricetin $(r=0.69)$; the phenolic acids gallic $(r=0.69)$ and caffeic $(r=0.79) ;$ and the anthocyanins pelargonidin 3-diglucoside $(r=0.67)$ and delphinidin 3-glucoside $(r=0.60)$. The correlations among the monomeric anthocyanins content were 0.89 and 0.74 $(p<0.01)$ for DPPH and ABTS, respectively, and for the phenolic compounds contents the correlations were 0.94 and 0.84 $(p<0.01)$, respectively. The correlation between the values obtained with the two methods used to measure the AOX (DPPH and ABTS) was also positive and significant at the $1 \%$ level, with a value of $r=0.88$. In a study carried out by Mudnic et al. (2010) the antioxidant activity of $1.0 \mathrm{mM} \mathrm{L}^{-1}$ solutions of nine phenolics acids was measured in vitro using the ABTS method, and high AOX values were verified for these compounds (for instance, $2.79 \mathrm{mM}, 1.42 \mathrm{mM}$ and $1.22 \mathrm{mM} \mathrm{TEAC} \mathrm{L}^{-1}$ for gallic, caffeic and $p$-coumaric acids, respectively). In a similar study, Muselík et al. (2007) determined in vitro the AOX of $1.0 \mathrm{mM} \mathrm{L}^{-1}$ solutions of monomeric anthocyanins and flavonoids using the ABTS method and verified that delphinidin 3glucoside was the anthocyanin which provided the highest AOX $(2.93 \mathrm{mM})$, followed by cyanidin 3-rutinoside $(2.77 \mathrm{mM})$. The authors also reported that epicatechin gallate $(5.31 \mathrm{mM})$, procyanidin B1 $(6.29 \mathrm{mM})$ and procyanidin B2 $(8.36 \mathrm{mM})$ were the flavonoids with highest AOX among those tested. These results could explain the high AOX values obtained for the juices investigated in this study, since among the compounds with positive correlations with AOX, catechin, procyanidin B2, caffeic acid, delphinidin 3-glucoside and the cyanidins mono- and diglucoside were the phenolic compounds present in highest concentrations in the juice samples. Positive correlations $(p<0.01)$ between the monomeric anthocyanins and total phenolic content of the grapes juices, with AOX measured by the DPPH method, have also been reported by other authors (Burin et al., 2010; Dani et al., 2007).

\section{Conclusions}

The concentration of phenolic compounds was found to be associated with the in vitro antioxidant activity of grape juices produced from new varieties of $V$. labrusca. The blending of the varieties BRS Violeta and BRS Cora with Isabel Precoce significantly increased the intensity of the juice colour as well as the total phenolic compounds and monomeric anthocyanins contents of the juices IPBC and IPBV. The flavonols, flavanols and anthocyanins were significantly correlated with the high antioxidant activity values obtained for the grape juices. The variety BRS Violeta provided a greater increase in the phenolic compounds content of the juice IP, and the variety BM showed good potential for use in commercial blends. The variety BRS Cora not only contributed to an increase in the colour and phenolic compounds in the juice IP, but was also responsible for an increase in the concentrations of organic acids such as tartaric and malic acids. The juices investigated showed relatively high concentrations of trans-resveratrol, notably the juice $\mathrm{BV}$, which provided a higher value than the other cultivars. Therefore, the use of blending with $V$. labrusca varieties is an appropriate approach to obtaining grape juices with higher concentrations of phenolic compounds associated with biological activities that are beneficial to the consumer's health. Notwithstanding, the new Brazilian varieties planted in the Northeast region of Brazil were found to contain acceptable quantities of bioactive compounds and possess the distinct characteristics associated with the tropical viticulture practised in the Sub-middle São Francisco Valley, which differ from those related to the traditional wine producing regions of the world.

\section{Acknowledgments}

The authors would like to acknowledge the Fundação de Amparo à Ciência e Tecnologia do Estado de Pernambuco - FACEPE 
for granting a scholarship and financial support (Projeto APQ0962-5.07/10). They are also grateful to The Cooperativa Agrícola Nova Aliança - COANA for providing the infrastructure, in-line process and raw materials used in the preparation of the grape juices.

\section{References}

Ali, K., Maltese, F., Choi, Y., \& Verpote, R. (2010). Metabolic constituents of grapevine and grape - derived products. Phytochemistry Reviews, 9(3), 357-378.

Brazil. Instrução Normativa no 01, de 07 de janeiro de 2000. Regulamento técnico geral para fixação dos padrões de identidade e qualidade para polpa de fruta. Diário oficial da república federativa do Brazil (pp. 54-58). Brasília, DF, 10 jan. 2000, Seção 1.

Burin, V. M., Falcão, L. D., Gonzaga, L. V., Fett, R., Rosier, J. P., \& Bordignon-Luiz, M. T. (2010). Colour, phenolic content and antioxidant activity of grape juice. Ciência e Tecnologia de Alimentos, 30(4), 1027-1032.

Camargo, U. A. (2004). 'Isabel Precoce': Alternativa para a vitivinicultura Brazileira (Vol. 54). Comunicado Técnico [Available from: <http:// www.cnpuv.embrapa.br/publica/comunicado/\#a2004>].

Camargo, U. A., Maia, J. D. G., \& Nachtigal, J. C. (2005). "BRS Violeta" nova cultivar de uva para suco e vinho de mesa (Vol. 63). Comunicado Técnico [Available from: <http://www.cnpuv.embrapa.br/publica/comunicado/\#a2005>].

Camargo, U. A., Tonietto, J., \& Hoffmann, A. (2011). Progressos na viticultura Brazileira. Revista Brasileira de Fruticultura E, 144-149.

Dani, C., Oliboni, L. S., Vanderlinde, R., Bonatto, D., Salvador, M., \& Henriques, J. A. P. (2007). Phenolic content and antioxidant activities of white and purple juices manufactured with organically- or conventionally-produced grapes. Food and Chemical Toxicology, 45, 2574-2580.

Dávalos, A., Bartolome, B., \& Gómez-Cordove's, C. (2005). Antioxidant properties of commercial grape juices and vinegars. Food Chemistry, 93, 325-330.

Fuleki, T., \& Ricardo-da-Silva, J. M. (2003). Effects of cultivar and processing method on the contents of catechins and procyanidins in grape juice. Journal of Agricultural and Food Chemistry, 51, 640-646.

Giusti, M. M., \& Wrolstad, R. E. (2001). Characterization and measurement of anthocyanins by UV-Visible spectroscopy. In Current protocols in food analytical chemistry. New York, USA: John Wiley and Sons Inc.

Granato, D., Katayama, F. C. U., \& Castro, I. A. (2011). Phenolic composition of South American red wines classified according to their antioxidant activity, retail price and sensory quality. Food Chemistry, 129, 366-373.

Gris, E. F., Mattivi, F., Ferreira, E. A., Vrhovsek, U., Pedrosa, R. C., \& Bordignon-Luiz, M. T. (2011). Proanthocyanidin profile and antioxidant capacity of Brazilian Vitis vinifera red wines. Food Chemistry, 126, 213-220.

Iyer, M. M., Sacks, G. L., \& Padilla-Zakour, O. I. (2010). Impact of harvesting and processing conditions on green leaf volatile development and phenolics in concord grape juice. Journal of Food Science, 75(3), 297-304.

Kim, Y. K., Guo, Q., \& Packer, L. (2002). Free radical scavenging activity of red ginseng aqueous extracts. Toxicology, 172, 149-156.

Krikorian, R., Boespflug, E. L., Fleck, D. E., Stein, A. L., Wightman, J. D., Shidler, M. D. et al. (2012). Concord grape juice supplementation and neurocognitive function in human aging. Journal of Agricultural and Food Chemistry, 60, 5736-5742.

Leblanc, M. R., Johnson, C. E., \& Wilson, P. W. (2008). Influence of pressing method on juice stilbene content in Muscadine and Bunch Grapes. Journal of Food Science, 73, N 4.

Liu, H.-F., Wu, B.-H., Fan, P.-G., Li, S.-H., \& Li, L.-S. (2006). Sugar and acid concentrations in 98 grape cultivars analyzed by principal component analysis. Journal of the Science of Food and Agricultural, 86, 1526-1536.

Lucena, A. P. S., Nascimento, R. J. B., Maciel, J. A. C., Tavares, J. X., Barbosa-Filho, J. M., \& Oliveira, E. J. (2010). Antioxidant activity and phenolics content of selected Brazilian wines. Journal of Food Composition and Analysis, 23, 30-36.

Malacrida, C. R., \& Motta, S. (2005). Compostos phenolics total e antocianinas em suco de uva. Ciência e Tecnologia de Alimentos, 25, 659-664.

Mello, L. M. R. (2013). Vitivinicultura Brazileira: Panorama 2012 (Vol. 137). Comunicado Técnico [Available from: <http://www.cnpuv.embrapa.br] publica/comunicado/\#a2013>].
Mudnic, I., Modun, D., Rastija, V., Vukovic, J., Brizic, I., Katalinic, V., et al. (2010). Antioxidative and vasodilatory effects of phenolic acids in wine. Food Chemistry, 119, 1205-1210.

Muselík, J., García-Alonso, M., Martín-López, M. P., Žemlička, M., \& Rivas-Gonzalo, J. C. (2007). Measurement of antioxidant activity of wine catechins, procyanidins, anthocyanins and pyranoanthocyanins. International Journal of Molecular Sciences, 8, 797-809.

Natividade, M. M. P., Corrêa, L. C., Souza, S. V. C., Pereira, G. E., \& Lima, L. C. O. (2013). Simultaneous analysis of 25 phenolic compounds in grape juice for HPLC: Method validation and characterization of São Francisco Valley samples. Microchemical Journal, 110, 665-674.

Organisation Internationale de la Vigne et du Vin. (2011). Recueil des methods internationals d'analyse des vins et des mouts, edition 2011. 8th Assemblée Générale, 21 June 2010, Paris.

Organisation Internationale de la Vigne et du Vin (2013). Vine and wine outlook 2008-2009. OIV - 18. Belgique: Peters SA [ISBN 979-10-91799-08-9. Available from: <http://www.oiv.int/oiv/info/esplubicationoiv> Accessed 11.2013].

Re, R., Pellegrini, N., Proteggente, A., Pannala, A., Yang, M., \& Rice-Evans, C. (1999). Antioxidant activity applying an improved ABTS radical cation decolorization assay. Free Radical Biology and Medicine, 26, 1231-1237.

Ribeiro, T. P., Lima, M. A. C., \& Alves, R. E. (2012). Maturação e qualidade de uvas para suco em condições tropicais, nos primeiros ciclos de produção. Pesquisa Agropecuária Brasileira, 47(8), 1057-1065.

Ritschel, P., Maia, J. D. G., Camargo, U. A., Zanus, M. C., Souza, R. T., \& Fajardo, T. G. M. . 'BRS Magna' nova cultivar de uva para suco com ampla adaptação climática (Vol. 125). Comunicado Técnico [Available from: <http://www.cnpuv.embrapa.br/ publica/comunicado/\#a2012>].

Rizzon, L. A., \& Miele, A. (2012). Analytical characteristics and discrimination of Brazilian commercial grape juice, nectar, and beverage. Ciência e Tecnologia de Alimentos, 32, 93-97.

Robbins, R. J., \& Bean, S. R. (2004). Development of a quantitative high-performance liquid chromatography-photodiode array detection measurement system for phenolic acids. Journal of Chromatography A, 1038, 97-105.

Sautter, C. K., Denardin, S., Alves, A. O., Mallmann, C. A., Penna, N. G., \& Hecktheuer, L. H. (2005). Determinação de resveratrol em sucos de uva no Brazil. Ciência e Tecnologia de Alimentos, 25, 437-442.

Singleton, V. L., \& Rossi, J. A. (1965). Colorimetry of total phenolics with phosphomolybdic phosphotungstic acid reagents. American Journal of Enology and Viticulture, 16, 144-158.

Soyer, Y., Koca, N., \& Karadeniz, F. (2003). Organic acid profile of Turkish white grapes and grape juices. Journal of Food Composition and Analysis, 16, 629-636.

Spayd, S. E., Tarara, J. M., Mee, D. L., \& Ferguson, J. C. (2002). Separation of sunlight and temperature effects on the composition of Vitis vinifera cv. Merlot berries. American Journal of Enology and Viticulture, 53, 171-182.

Stalmach, A., Edwards, C. A., Wightman, J. D., \& Crozier, A. (2011). Identification of (poly)phenolic compounds in Concord grape juice and their metabolites in human plasma and urine after juice consumption. Journal of Agricultural and Food Chemistry, 59, 9512-9522.

Talcott, S. T., \& Lee, J.-H. (2002). Ellagic acid and flavonoid antioxidant content of Muscadine wine and juice. Journal of Agricultural and Food Chemistry, 50, 3186-3192.

Vauzour, D., Rodriguez-Mateos, A., Corona, G., Oruna-Concha, M. J., \& Spencer, J. P. E. (2010). Polyphenols and human health: Prevention of disease and mechanisms of action. Nutrients, 2, 1106-1131.

Vitrac, X., Bornet, A., Vanderlinde, R., Valls, J., Richard, T., Delaunay, J. C., et al. (2005). Determination of stilbenes (delta-viniferin, transastringin, trans-piceid, cis- and trans-resveratrol, epsilon-viniferin) in Brazilian wines. Journal of Agricultural and Food Chemistry, 53(14), 5664-5669.

Wang, H., Race, E. J., \& Shrikhande, A. J. (2003). Characterization of anthocyanins in grape juices by ion trap liquid chromatography-mass spectrometry. Journal of Agricultural and Food Chemistry, 51, 1839-1844.

Xia, E.-Q., Deng, G. F., Guo, Y.-J., \& Li, H.-B. (2010). Biological activities of polyphenols from grapes. International Journal of Molecular Sciences, 11, 622-646. 